\title{
DISTRIBUTION AND ABUNDANCE OF CLADOCERA (BRANCHIOPODA) IN THE PARAÍBA DO SUL RIVER ESTUARY, RIO DE JANEIRO, BRAZIL
}

\author{
José Mauro Sterzal \& Luiz Loureiro Fernandes ${ }^{2}$ \\ ${ }^{1}$ Universidade Estadual do Norte Fluminense - UENF \\ Centro de Biociências e Biotecnologia - Laboratório de Ciências Ambientais \\ (Av. Alberto Lamego, 2000, Pq. Califórnia 28013-602, Campos dos Goytacazes, RJ, Brasil) \\ jmsterza@yahoo.com.br \\ ${ }^{2}$ Universidade Federal do Espírito Santo - UFES \\ Departamento de Ecologia e Recursos Naturais \\ (Av. Fernando Ferrari, 514, 29060-900 Vitória, ES, Brasil)
}

\section{A B S T R A C T}

To characterize the cladoceran community of the Paraíba do Sul River estuary, located in the district of São João da Barra, Rio de Janeiro, Brazil, cladocerans were collected monthly in nine sampling stations from September 2002 until August 2003. Samples were obtained by subsurface tows using a plankton net with a $30 \mathrm{~cm}$ opening mouth and 70 micron mesh size, fitted with a mechanical flowmeter. Environmental parameters such as salinity and temperature were also obtained. Seventeen species of Cladocera were identified: Pseudoevadne tergestina, Penilia avirostris, Macrothrix triserialis, Moina micrura, Simocephalus kerhervei, Simocephalus vetalus, Simocephalus latirostris, Simocephalus serrulatus, Alona rectangula, Alona quadrangularis, Bosmina longirostris, Bosminopsis deitersi, Camptocercus dadayi, Ceriodaphnia richardi, Diaphanosoma fluviatile, Kurzia latissima and Pleuroxus similis. The highest total abundance of Cladocera occurred in April in the marine zone of the estuary. The most abundant species during this period was Penilia avirostris. At the mixing and freshwater zones of the estuary, the most abundant species were Moina micrura, mainly in January; and Simocephalus vetalus and Bosmina longirostris during spring. From this scenario, it can be inferred that the cladoceran community of the Paraíba do Sul River estuary presents characteristics of marine, brackish and freshwater environments. Temperature and salinity seem to limit the occurrence and distribution of cladocerans in the estuary.

\section{RESUMO}

O presente estudo teve como objetivo caracterizar a comunidade zooplanctônica de cladóceros no estuário do Rio Paraíba do Sul, localizado no município de São João da Barra, RJ. O zooplâncton foi coletado mensalmente de setembro/2002 a agosto/2003 em nove estações através de arrastos subsuperficiais com uma rede de plâncton com abertura de boca de $30 \mathrm{~cm}$ e malha de $70 \mathrm{m \mu}$, dotada de fluxômetro mecânico. Foram medidas simultaneamente a salinidade e a temperatura. Foram identificadas dezessete espécies de cladóceros: Pseudoevadne tergestina, Penilia avirostris, Macrothrix triserialis, Moina micrura, Simocephalus Kerhervei, Simocephalus vetalus, Simocephalus latirostris, Simocephalus serrulatus, Alona rectangula, Alona quadrangularis, Bosmina longirostris, Bosminopsis deitersi, Camptocercus dadayi, Ceriodaphnia richardi, Diaphanosoma fluviatile, Kurzia latissima e Pleuroxus similis. As maiores abundâncias de cladóceros ocorreram no mês de abril na zona marinha do estuário. A espécie mais abundante nesse período foi Penilia avirostris. Na zona de mistura e fluvial do estuário, as espécies mais abundantes foram Moina micrura, principalmente durante o mês de janeiro; Simocephalus vetalus e Bosmina longirostris na primavera. Diante desse cenário, pode-se dizer que a comunidade de cladóceros no estuário do Rio Paraíba do Sul apresenta características de ambientes marinhos, estuarinos e limnicos. A salinidade e a temperatura parecem limitar a ocorrência e distribuição dos cladóceros no estuário.

Descriptors: Zooplankton; Estuary; Cladocera; Salinity.

Descritores: Zooplâncton; Estuário; Cladocera; Salinidade.

\section{INTRODUCTION}

Estuaries constitute an important transition region between terrestrial and marine environments, with rivers as the main thoroughfare for materials from continental leaching to estuaries and coastal zones
(Garrels \& Mackenzie, 1971). In general, estuarine waters are biologically more productive than freshwater systems and the adjacent ocean, due to their hydrodynamic circulation characteristics that retain nutrients, stimulate production (Miranda et al., 2002), and produce high auto- and heterotrophic biomass (Nixon, 1981). 
Tidal hydrodynamics have a strong effect on the composition and zonation of resident and temporary organisms in pelagic habitats. Combined with river discharge, tides influence the regulation of planktonic population by translocation of individuals from one place to another within and even to the outside of the estuary (Villate, 1997; Wooldridge \& Callahan, 2000). Estuarine waters are characterized by high turbidity, turbulence and strong tidal currents, resulting in an environment in which organisms need to show specific adaptations. This, along with the limited exchange with coastal waters, results in the development of a distinct pelagic community (Miller, 1983).

Tidal effects on the regulation of estuarine zooplankton can be especially relevant in small system where strong river discharges occur (Kennish, 1990). Tides are not only responsible for distributional patterns, but also affect the survival of endemic populations through export of water masses and consequent reduction of resident populations (Kennish, 1990).

The neritic populations of areas with coastal, intermediate and freshwater inputs influence the relative development of estuarine systems through salinity variations (Tundisi, 1970; Lansac-Tôha \& Lima, 1993; Lopes, 1994). Primary production is transferred to higher trophic levels through mesozooplankton. Estuarine plankton need to be able to respond to great physical-chemical changes in the environment, which influence daily and seasonal distributional patterns, and thus population dynamics. All these environmental and biological factors restrict the variety of zooplankton species in estuaries compared to marine areas, but the high primary productivity levels in estuaries can make these species very abundant (Summerhayes \& Thorpe, 1998).

Cladocerans form a typical limnic group, although some marine species do exist (ElmoorLoureiro, 1997). They are generally seen as a secondary component of the estuarine zooplankton, even though they may compose a significant fraction of the zooplanktonic community. When abundant, they can be an important food item for planktivorous fish and other zooplanktonic predators, and perform a significant role in production of organic matter (Marazzo \& Valentin, 2004).

Studies on cladocerans in other countries are concentrated in lakes (Hobaek et al., 2002) and wetlands (Hann \& Zrum, 1997). There are few studies on cladocerans in tropical estuarine regions. Very little is known on the life habits of the cladoceran species found in Brazil (Elmoor-Loureiro, 1997), the majority of studies focusing on limnic environments such as reservoirs and lakes (Sampaio et al., 2002; SantosWisniewski et al., 2002; Elmoor-Loureiro et al., 2004) and flooded river plains (Neves et al., 2003;
Serafim Jr. et al., 2003). On marine environments, there are works by Marazzo \& Valentin $(2000 ; 2001)$ and Valentin \& Marazzo (2003) at Guanabara Bay; Resgalla Jr. \& Montú (1993) on the coast of Rio Grande do Sul State. There is no current work on cladoceran communities of estuaries influenced by large rivers such as the Paraíba do Sul. Therefore, the present study characterizes the cladoceran community of the Paraíba do Sul River estuary, located in the district of São João da Barra, Rio de Janeiro State, and evaluates its distribution in different hydrodynamic and hydrochemical conditions.

\section{Material and Methods}

\section{Study Area}

The Paraíba do Sul River estuary is located between the districts of São João da Barra and São Francisco do Itabapoana $\left(21^{\circ} 37^{\prime} \mathrm{S}\right.$ and $\left.41^{\circ} 00^{\prime \prime} \mathrm{W}\right)$, with a mangrove zone of approximately $8 \mathrm{~km}^{2}$ (Fig. $1)$. It is the second largest river in the littoral zone of the southeast area of Brazil, 1,150 km long, and a drainage area of approximately $55,500 \mathrm{~km}^{2}$, extending through the states of São Paulo, Minas Gerais and Rio de Janeiro. Its upper part extending from São Fidélis city to the source, is $95 \mathrm{~km}$ long with an average declivity of $0,22 \mathrm{~m} \cdot \mathrm{km}^{-1}$, crossing the Campista low lands, comprising sedimentary soil of fluvial-marine origin, and ultimately discharging into the Atlantic Ocean (Fig. 1). Besides domestic and industrial uses, resources of the river basin are intensively exploited by agriculture, fishing, navigation and for energy generation (CEIVAP, 2001; DNAEE, 1995).

Salinity within the Paraíba do Sul River estuary is regulated by riverine input, tides and coastal currents. The extent of the river plume is determined by several factors such as winds, currents and riverine input (Carneiro, 1998). The rainfall regime in the catchment area of the Paraíba do Sul River shows a period of intense rain activity (November to January) causing floods and a very dry period (July to August). River flow ranges from 155 to $2984 \mathrm{~m}^{3} . \mathrm{s}^{-1}$ with the highest flow between December and March, and the lowest from June to October (DNAEE, 1995). These conditions certainly influence the zooplankton, especially during the flood periods.

\section{Sampling}

Sampling was performed monthly during a period of 12 months (September 2002 - August 2003) along the saline gradient of the main estuary channel at 9 sampling locations, 5 within the river plume and 4 in the estuary proper (Fig. 1). All samples were taken during flood tide. 

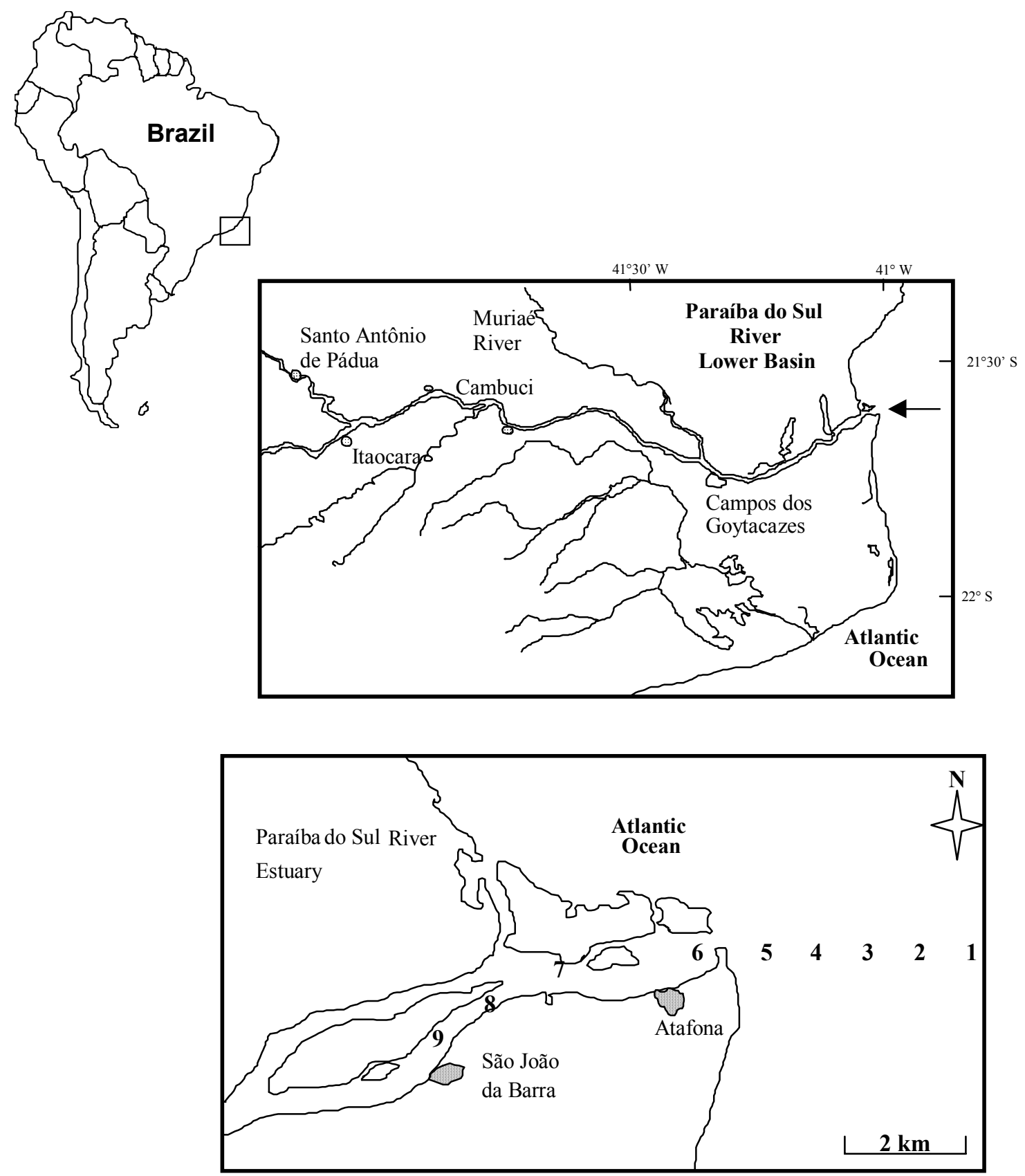

Fig. 1. Map of the study area with the sampling stations.

Samples were collected by sub-surface tows with a plankton net of $30 \mathrm{~cm}$ mouth opening and 70 $\mu \mathrm{m}$ mesh size, fitted with a mechanical flowmeter to estimate the amount of water filtered (ElmoorLoureiro, 1997; Kramer et al., 1994; Omori \& Ikeda 1992). Biological material was fixed in an aqueous solution of $5 \%$ formalin, buffered with sodium tetraborate, for later analyses in the laboratory.

For each sample collected, aliquots were taken with a Folsom plankton splitter according to the degree of concentration of the original sample. All individuals within each aliquot were identified and 
counted. Species were identified to the lowest taxonomic level according to the literature (Boltovskoy, 1981; 1999; Montú \& Gloeden, 1986; Edmondson, 1959; Elmoor-Loureiro, 1997), using a ZEISS Stemi2000 stereoscopic microscope and an Olympus CX41 optical microscope.

Environmental Variables

In situ temperature and salinity were measured at the surface and bottom with a portable field multi-sounde YSI65.

\section{Statistical Outline}

Type I Analysis of Variance (ANOVA) was applied to the environmental parameters (temperature and salinity), total abundance of cladocerans and the density of the most abundant species to test differences between sampling time (temporal patterns) and sampling stations (spatial patterns). To equalize the variance and normalize distributions, all data used in the ANOVA were $\log _{10}(\mathrm{x}+1)$ transformed, but it was not possible to normalize cladoceran abundance. However, ANOVA was performed since this type of analysis is more robust than non-parametric analyses (Underwood, 1997). Normal data distribution and homogeneity of variances were tested with the Kolmogorov-Smirnov test with a $p<0.05$. When significant differences were detected by the ANOVA, Tukey's Honestly Significantly Different (HSD) test was applied to identify the sources of variation. Analyses were performed using STATISTICA 6.0 software (Statsoft Inc.).

\section{RESUlts}

Environmental Variables

Salinity varied from 0.0 at the inner estuary, mainly during the rainy season (January, February and March), to 37.1 at stations located in the estuarine plume during July. Analysis of variance showed significant differences between the sampling locations (Fig. 2). Sampling stations located in the estuarine plume showed salinity values significantly higher than located in the inner estuary (ANOVA $F=26.97 ; p=$ $0.00)$.

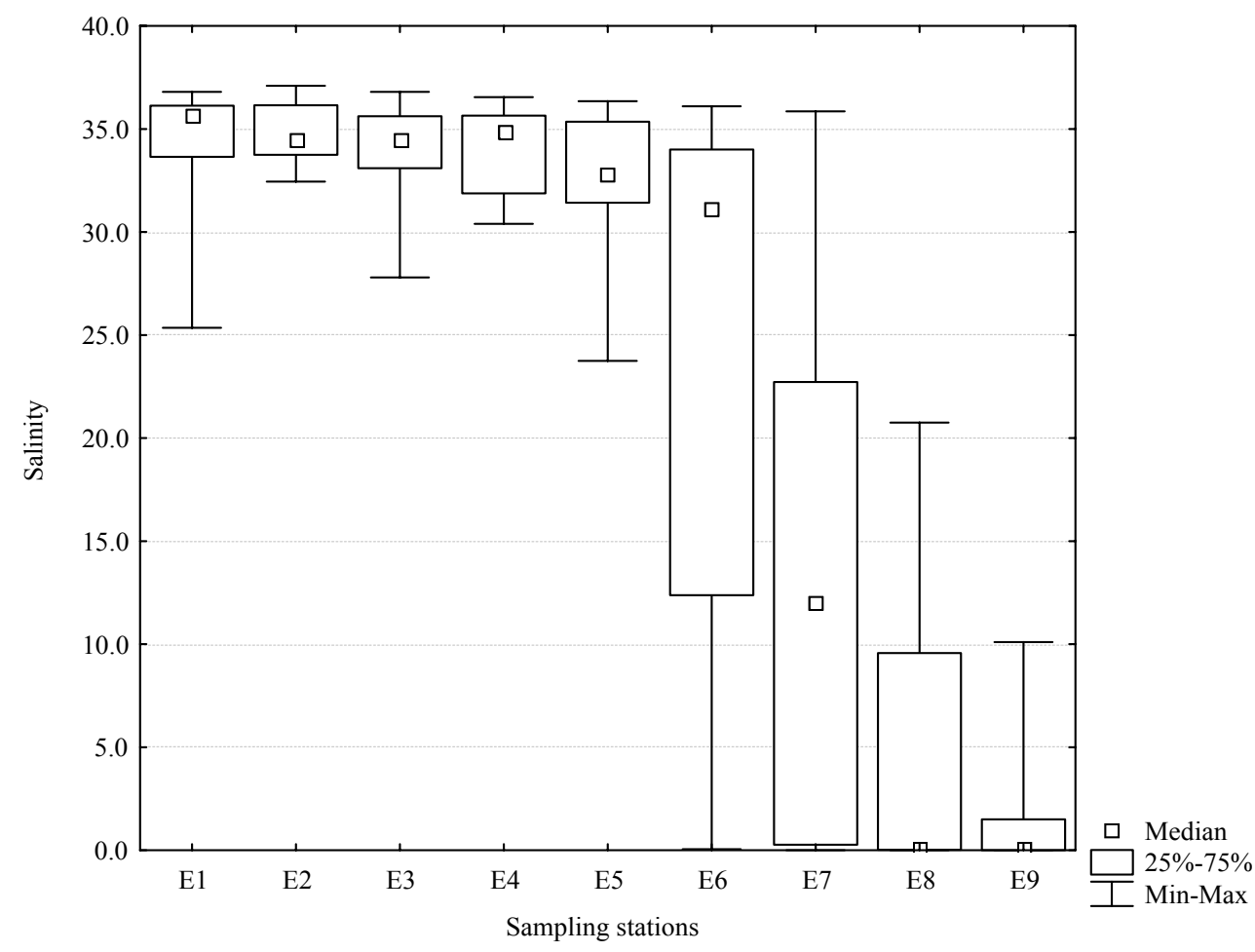

Fig. 2. Average salinity values $(n=108)$ along the sampling stations. 
Temperature varied from $21.8^{\circ} \mathrm{C}$ in August to $30.9^{\circ} \mathrm{C}$ in February (Fig. 3). Through the analysis of variance it was possible to detect significant differences among the sampling months, when temperature values in the summer were significantly higher than those in winter (ANOVA $F=16.30 ; p=$ $0.00)$. There were no significant differences between sampling stations (ANOVA $F=2.07 ; p=0.02$ ).
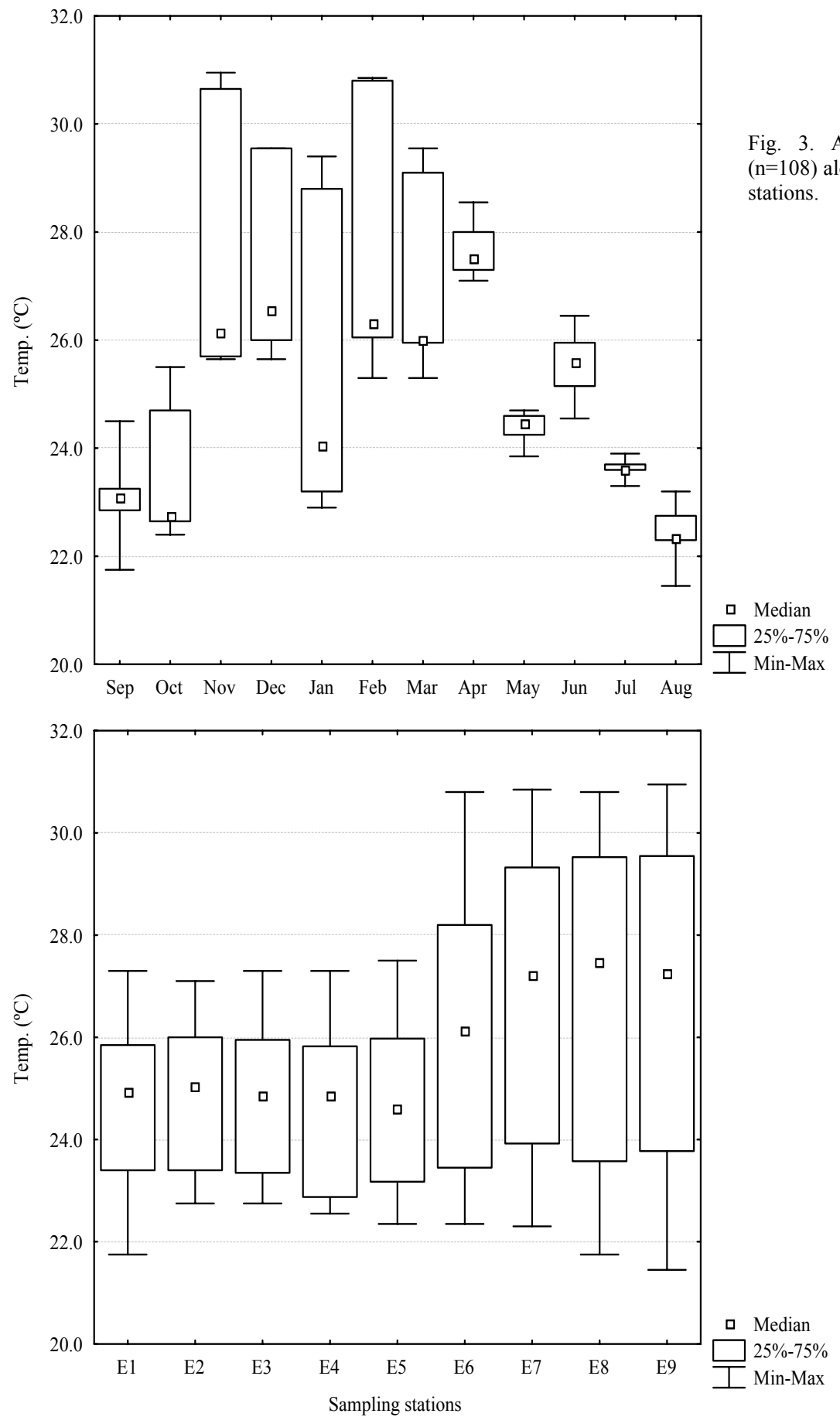
Cladoceran Community

Seventeen species were identified: Pseudoevadne tergestina, Penilia avirostris, Macrothrix triserialis, Moina micrura, Simocephalus Kerhervei, Simocephalus vetalus, Simocephalus latirostris, Simocephalus serrulatus, Alona rectangula, Alona quadrangularis, Bosmina longirostris, Bosminopsis deitersi, Camptocercus dadayi, Ceriodaphnia richardi, Diaphanosoma fluviatile, Kurzia latissima and Pleuroxus similis.

Total cladoceran abundance varied from 0 to 17.294 Ind. $^{-3}$, with significantly higher values in April (ANOVA $F=2.41 ; p=0.01$ ) at sampling stations located in the marine zone of the estuary (Fig. 4). There were no significant differences in total abundance among stations (ANOVA $F=0.83 ; p=$ $0.57)$.

The most abundant species during the study period was Penilia avirostris, varying from 0 to 17.294 Ind. I $^{-3}$ (Fig. 5). P. avirostris was significantly more abundant in February, March and April (ANOVA
$F=5.94 ; p=0.00)$. Estuarine plume sampling stations showed significantly higher values than stations located in the inner estuary (ANOVA $F=5.46$; $p=$ $0.00)$.

Another abundant species was Moina micrura which varied from 0 to 3.226 Ind. $^{-3}$ (Fig. 6). It was most abundant in January (ANOVA $F=4.94$; $p=0.00)$ and at stations located in the inner estuary (ANOVA $F=8.22 ; p=0.00$ ), where salinity was close to zero.

Simocephalus vetalus was significantly more abundant in October (ANOVA $F=2.98 ; p=0.00$ ) and varied from 0 to 731 Ind.m ${ }^{-3}$ (Fig. 7). Higher abundances occurred at stations located in the inner estuary, mainly at the river portion (ANOVA $F=7.84$; $p=0.00$ ). Bosmina longirostris abundance varied from 0 to 199 Ind. $\mathrm{m}^{-3}$ and showed significant differences among the months, occurring mainly in October (ANOVA $F=2.46 ; p=0.01$ ). Higher abundances occurred again at stations located in the inner estuary (Fig. 8), mainly at the river portion (ANOVA $F=5.01$; $p=0.00$ ).

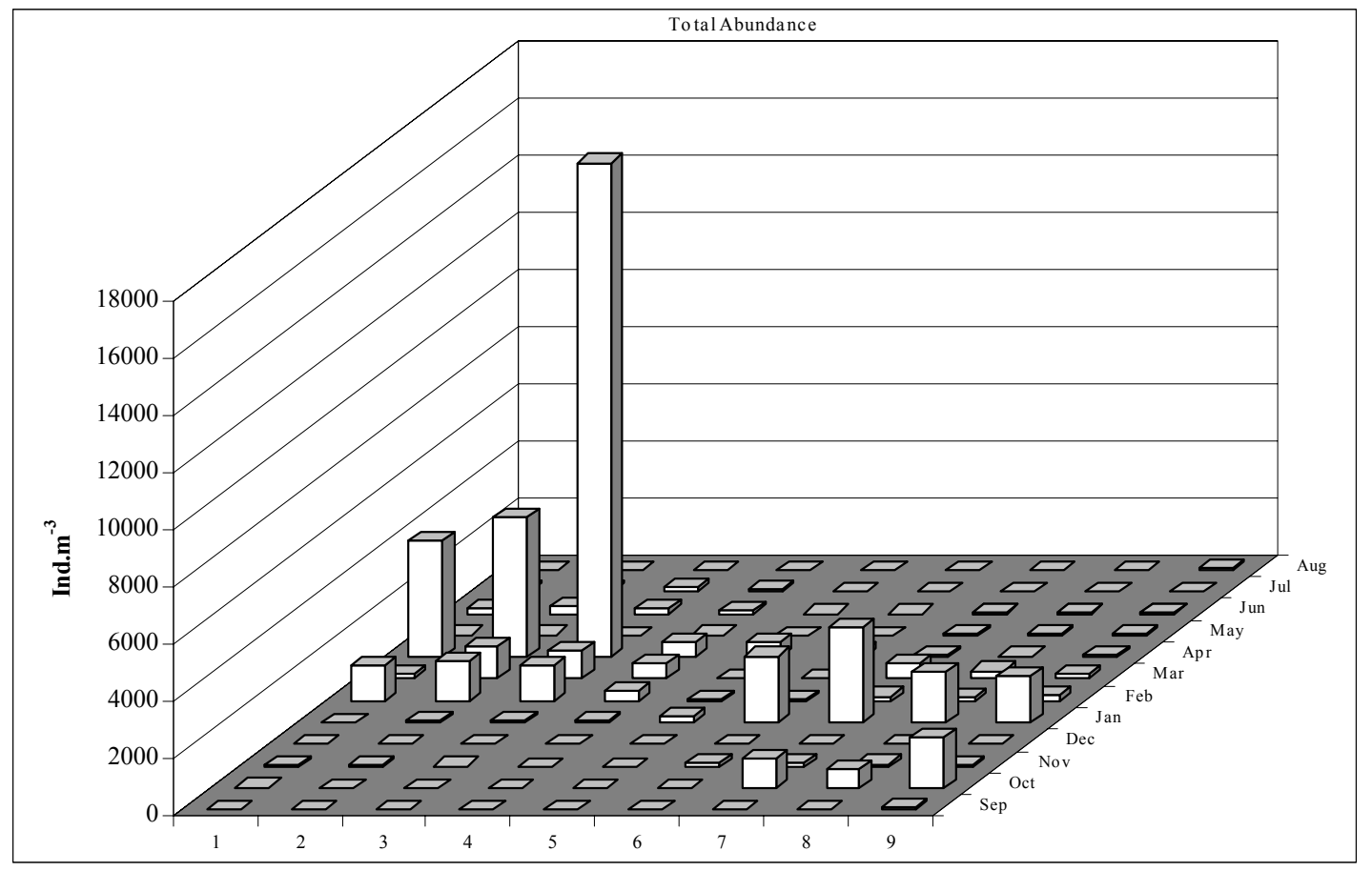

Fig. 4. Total monthly cladoceran abundance (Ind. $\mathrm{m}^{-3}$ ) along the sampling stations (1 to 9). 


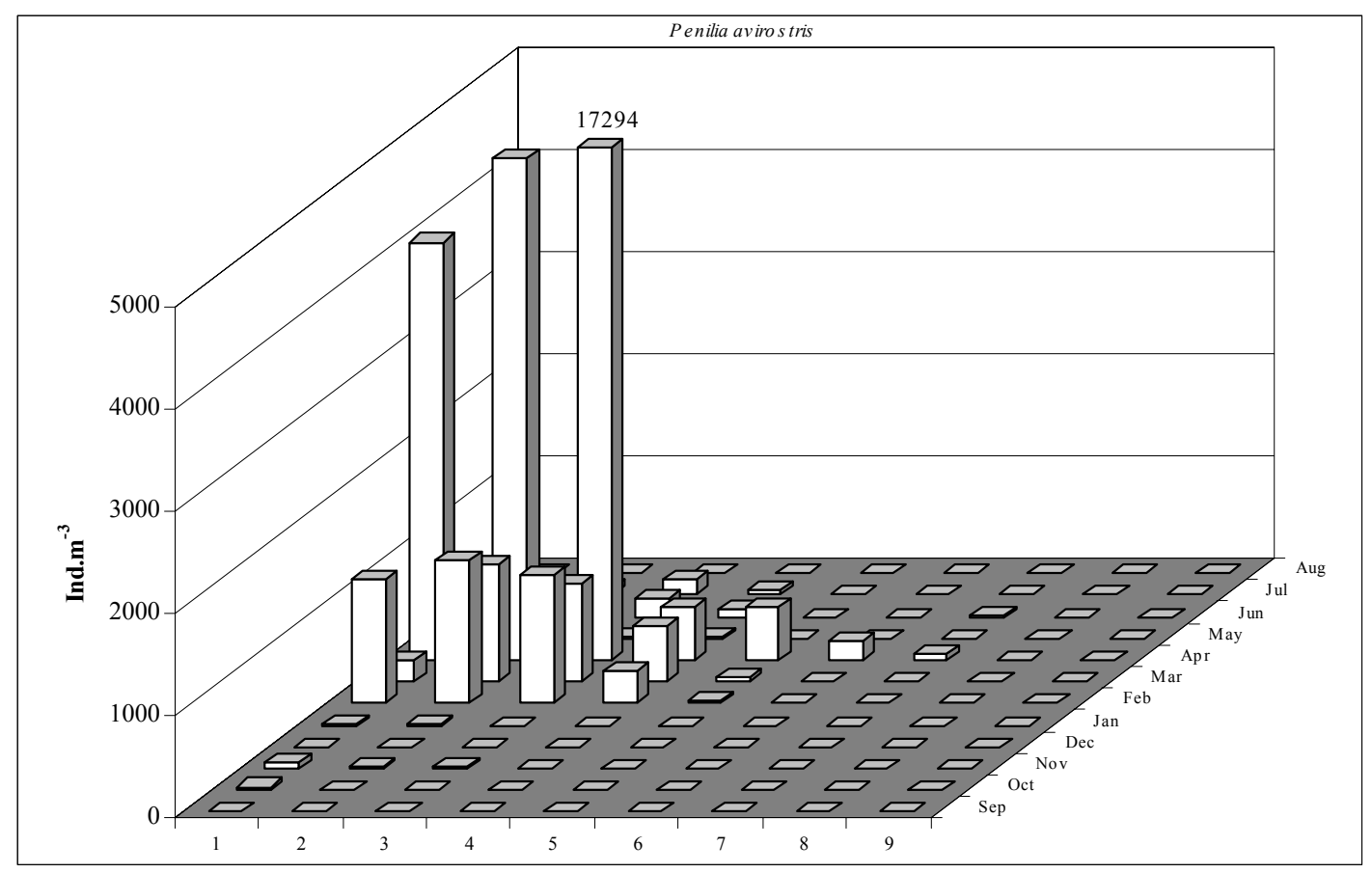

Fig. 5. P. avirostris total monthly abundance ( $\mathrm{n}=108)$ along the sampling stations (1 to 9$)$.

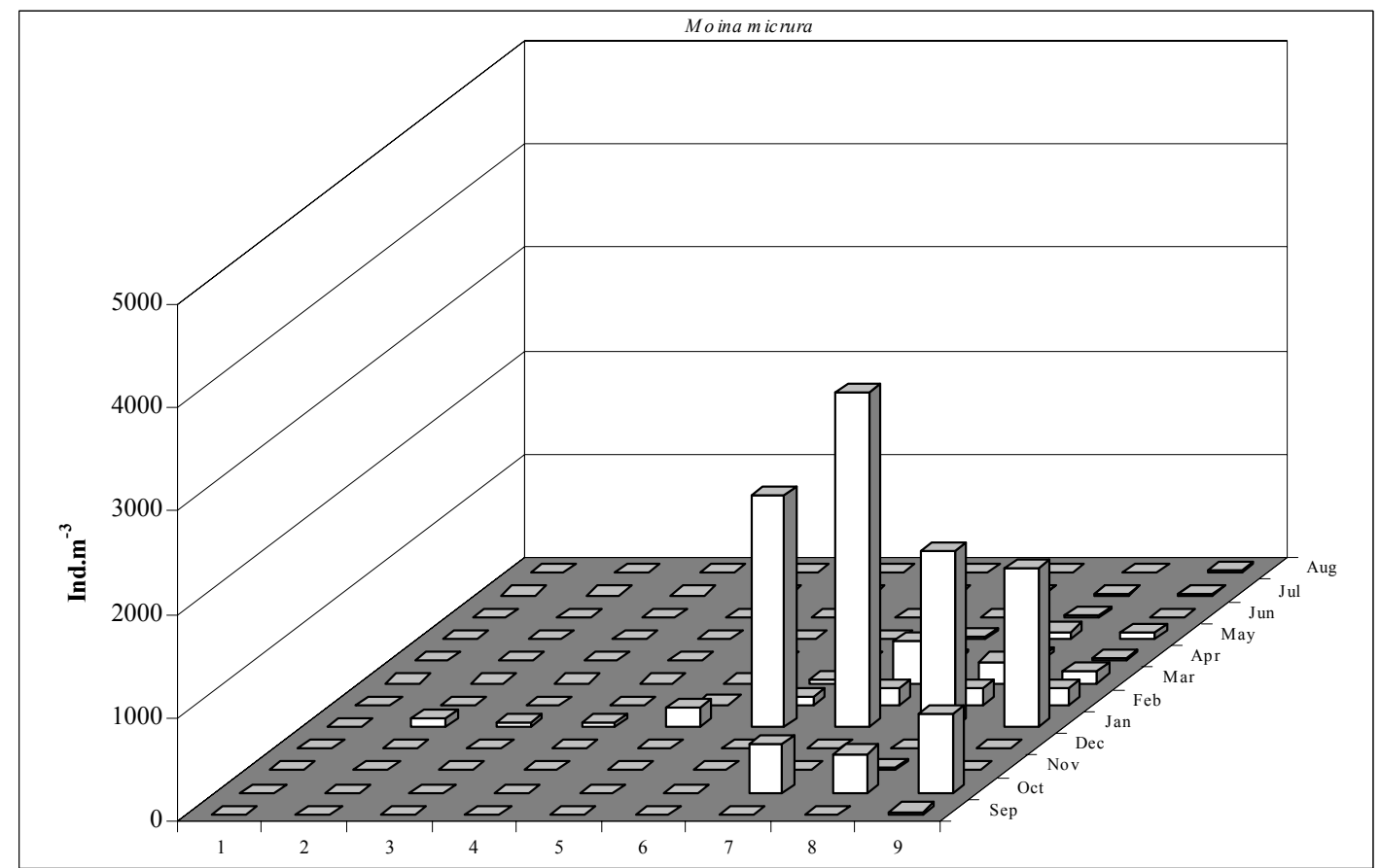

Fig. 6. M. micrura total monthly abundance ( $\mathrm{n}=108)$ along the sampling stations (1 to 9$)$. 


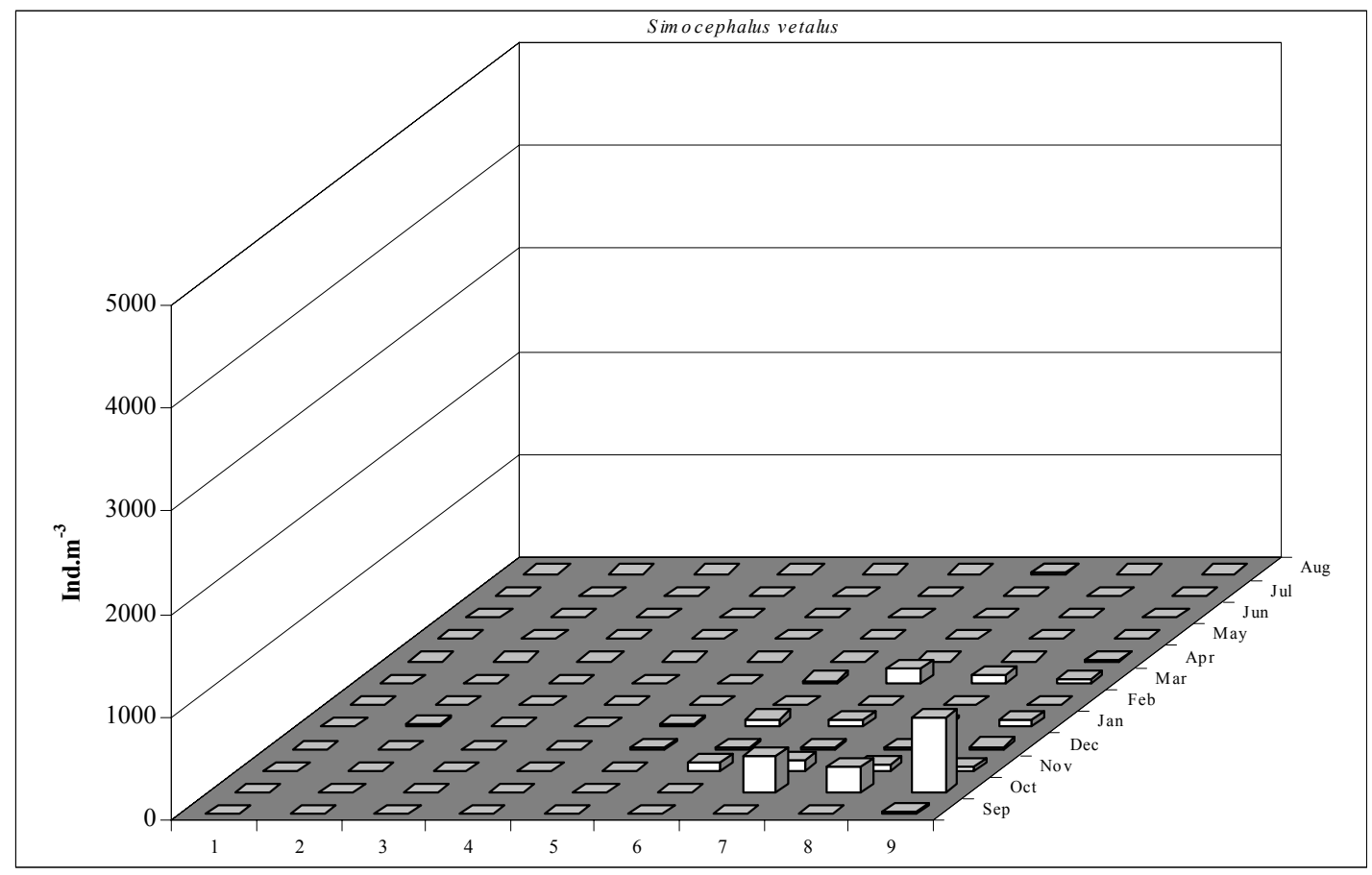

Fig. 7. S. vetalus total monthly abundance $(\mathrm{n}=108)$ along the sampling stations (1 to 9$)$.

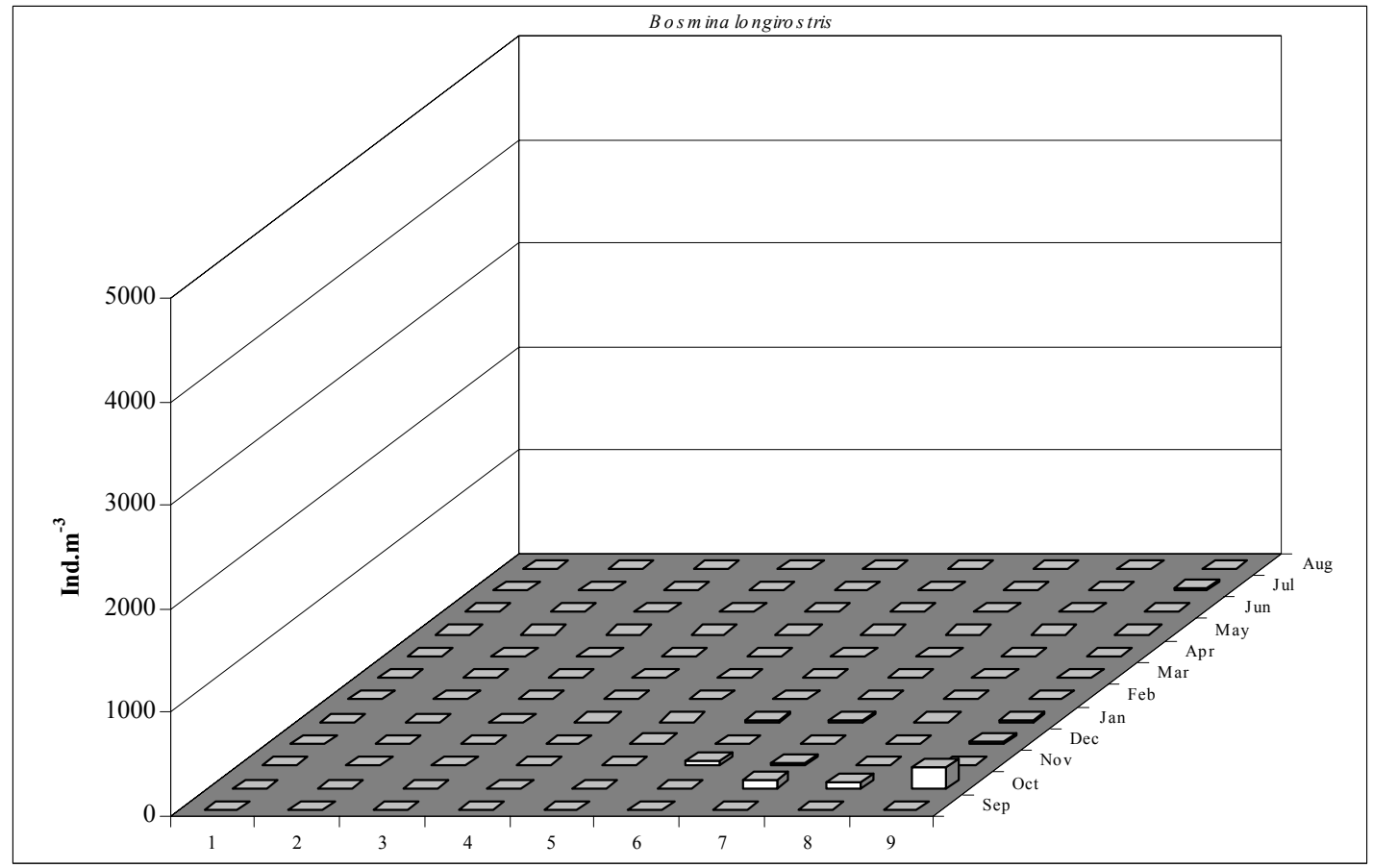

Fig. 8. B. longirostris total monthly abundance $(\mathrm{n}=108)$ along the sampling stations $(1$ to 9$)$. 
Environmental Variables x Cladoceran Community

P. avirostris occurred mainly at stations located in the estuarine plume, where salinity values were higher and during the warmer months (Fig. 2). M. micrura, S. vetalus and B. longirostris had their highest abundances at stations located in the inner estuary. Also, M. micrura occurred mainly during the warmer months (Fig.3).

\section{DisCUSSION}

The species of cladocerans (Table 1) found in the study area are typical of marine and estuarine environments (Coelho-Botelho et al., 1999; Lopes, 1996; Montú, 1980; Nogueira et al., 1999; Valentin \&
Marazzo, 2003; Marazzo \& Valentin 2004), but most are from freshwater environments (Elmoor-Loureiro, 1997; Elmoor-Loureiro et al., 2004; Hann \& Zrum, 1997; Montú, 1980; Neves et al., 2003; SantosWisniewski et al., 2002; Sampaio et al., 2002; Serafim Jr. et al., 2003).

The cladoceran community at the Paraíba do Sul River estuary showed an intermediate species richness between freshwater and marine environments. In freshwater, the species number is greater, since 26 species were found in lakes of reservoirs by Sampaio et al. (2002); in rivers, 30 species were found by Neves et al. (2003) and 63 species by Serafim Jr. et al. (2003). The results of the present study are expected since this is a transitional environment.

Table 1. Cladoceran species occurrence at the Paraíba do Sul river estuary in Brazil (Elmoor-Loureiro, 1997; Marazzo \& Valentin, 2000; 2001; Montú. \& Gloeden, 1986).

\begin{tabular}{lcl}
\hline \hline Species & Environment & \\
\hline $\begin{array}{l}\text { Pseudoevadne tergestina } \\
\text { Penilia avirostris }\end{array}$ & Estuarine, marine & Location \\
Moina micrura & Estuarine, marine & Rio de Janeiro, Rio Grande do Sul \\
Macrothrix triserialis & Freshwater, estuarine & Alagoas, Pernambuco, Minas Gerais \\
Simocephalus kerhervei & Freshwater & Pará, Mato Grosso, Pernambuco \\
Simocephalus latirostris & Freshwater & São Paulo \\
Simocephalus vetalus & Freshwater & Amazonas, Pernambuco \\
Simocephalus serrulatus & Freshwater & Pernambuco, Rio Grande do Sul \\
Alona rectangula & Freshwater & Minas Gerais, São Paulo \\
Alona quadrangularis & Freshwater & Roraima, Mato Grosso, Minas Gerais \\
Bosmina longirostris & Freshwater & Pará, São Paulo \\
Bosminopsis deitersi & Freshwater & Maranhão, Distrito Federal, São Paulo \\
Camptocercus dadayi & Freshwater, estuarine & Acre, Mato Grosso, Rio Grande do Sul \\
Ceriodaphnia richardi & Freshwater, estuarine & Piauí, Rio Grande do Sul \\
Diaphanosoma fluviatile & Freshwater & São Paulo \\
Kurzia latissima & Freshwater, estuarine & Amazonas, Rio Grande do Sul, Pará \\
\hline Fleuroxus similis & Rreshwater, estuarine & Grande do Sul \\
\hline
\end{tabular}


Most of cladoceran species recorded in the present study occurred in the warmer and wet months. Salinity seems to limit the occurrence and distribution of cladocerans in the Paraíba do Sul River estuary. Since the majority of the species are from freshwater, these appear in higher quantities in the estuary during the periods of high river water input, when salinity values approach zero at the inner portion of the system (e.g Moina micrura). Lansac Tôha \& Lima (1993), working in the Una do Prelado River estuary (São Paulo State) observed that coastal species were found in the inner portion of the estuary during the high tide, but freshwater species invaded the estuary during low tide, especially during the rainy season. Associated to low salinity, high temperature must also be considered (Lansac Tôha \& Lima 1993; Montú, 1980).

High abundance of cladocerans in the coastal region was related to the occurrence of Penilia avirostris, most abundant during fall. Although it is a marine species, it can penetrate the estuary during the flood tide during periods of low freshwater input. This species is an important component of the zooplankton in coastal and estuarine waters like in the coast off Rio de Janeiro state in certain periods of the year, along with other species such as Pseudoevadne tergestina and Pleopis polyphemoides (Coelho-Botelho et al., 1999; Nogueira et al., 1999; Marazzo \& Valentin, 2004), and is an important contributor to secondary production (Marazzo \& Valentin, 2004). However, Penilia avirostris may disappear from the plankton at certain periods (Valentin \& Marazzo, 2003). In Guanabara Bay, Marazzo \& Valentin (2001) observed that Penilia avirostris reached its maximum density during fall and disappeared in the winter and spring, as recorded in the present study.

The highest abundance of Moina micrura during summer is due to the higher freshwater input during this period, which blocks the entrance of salty waters into the estuary. Consequently this species does not seem to be able to survive in brackish waters in the Paraíba do Sul River estuary, despite being considered an euryhaline-limnetic species, occurring in other environments with salinities from 0-31.5 (Montú, 1980). This is another cladoceran species that may occur in several types of freshwater bodies (Elmoor-Loureiro et al., 2004; Montú, 1980), a good indicator of the trophic state of the environment (Sampaio et al., 2002). In Brazil, it has been recorded in the states of Alagoas, Pernambuco, Mato Grosso do Sul, Minas Gerais, Rio Grande do Sul and in the Distrito Federal (Elmoor-Loureiro, 1997).

Although Simocephalus vetalus is a typical freshwater species, its presence in oligohaline waters during spring shows a certain tolerance to brackish waters. This species occurs frequently in wetlands (Hann \& Zrum, 1997), abundant in the summer in areas close to macrophytes. It has been recorded in the states of Pernambuco and Rio Grande do Sul (ElmoorLoureiro, 1977). The same occurred with Bosmina longirostris, which was recorded in brackish waters during spring. This species seems to be also abundant in wetlands during spring (Hann \& Zrum, 1997); lakes (Elmoor-Loureiro et al., 2004) and rivers (Serafim Jr. et al., 2003). It is also a good indicator of the trophic state of lakes, particularly of eutrophic environments (Sampaio et al., 2002). It is cosmopolitan, present in the states of Maranhão, São Paulo, Rio Grande do Sul, Minas Gerais and Distrito Federal (Elmoor-Loureiro, 1997).

Penilia avirostris abundance peaks in the fall may be associated with the stability of the salinity values in the water column and the elevated temperature values. The same happens to Simocephalus vetalus and Bosmina longirostris, where their presence in the estuary during spring shows that temperature is probably a controlling factor. Moina micrura however, has its occurrence limited to the presence of saline waters in the estuary. The composition and abundance of zooplankton communities can be influenced by several physical, chemical and biological factors (Neves et al., 2003; Sampaio et al., 2002). Temperature can cause changes in community composition as well as density. Temperature controls reproductive rates, species population size and metabolism (Sampaio et al., 2002) all of them the most important factors determining seasonal distribution of marine cladocerans (Marazzo \& Valentin, 2004). Other factors such as salinity, dissolved oxygen, tidal currents, can also affect the occurrence and distribution of cladocerans in estuarine environments (Valentin \& Marazzo, 2003; Marazzo \& Valentin, 2004), salinity being one of the key factors determining the distribution of species of different origin (Montú, 1980). Based on salinity data, it can be concluded that the only species presenting truly estuarine characteristics was Penilia avirostris. This species is typically marine and can penetrate the estuary during the periods of low freshwater input into the flood tide, as observed by Lansac Tôha \& Lima (1993) at the Una do Prelado River estuary (SP). In periods of high freshwater input, the estuary is invaded by freshwater species such as Moina micrura.

\section{Conclusions}

Cladoceran community of the Paraíba do Sul River estuary shows characteristics of marine, estuarine and freshwater environments. Salinity and temperature limit the occurrence and distribution of the cladocerans in the estuary. Seventeen species of cladocerans have been identified in the Paraíba do Sul River estuary. Highest abundances occur during the 
month of April at the marine zone of the estuary, dominated by Penilia avirostris. In the mixture and riverine zone of the estuary the most abundant species has been Moina micrura, especially during January, and its occurrence is limited to the presence of saline waters. Simocephalus vetalus and Bosmina longirostris occur mainly in the spring in oligohaline waters.

\section{REFERENCES}

Boltovskoy, D. (ed.). 1981. Atlas de zooplancton del Atlántico Sudoccidental. Mar del Plata: INIDEP. 936 p.

Boltovskoy, D. (ed.). 1999. South Atlantic Zooplankton. Leiden: Backhuys Publishers, $1706 \mathrm{p}$.

CEIVAP - Comitê para integração da Bacia Hidrográfica do rio Paraíba do Sul. 2001. Brasília, DF: Bacia do rio Paraíba do Sul: Livro da Bacia. 68p.

Coelho-Botelho, M. J.; Mauro, J. B. N.; Dias, C. de O.; Kurtz, F. W.; Truzzi, A. C.; Nogueira, C. R.; Reis, J. L. dos \& Mathias, A. M. da F. 1999. Aspéctos do zooplâncton na baía de Sepetiba (RJ, Brasil). In: Silva, S. H. G. \& Lavrado, H. P. eds. Ecologia dos ambientes costeiros do estado do Rio de Janeiro, ser. Oecologia Brasiliensis. Rio de Janeiro: PPGE-UFRJ, v.7, p.1-33.

DNAEE - Departamento Nacional de Águas e Energia Elétrica. Implantação de uma agência para a Bacia do Rio Paraíba do Sul. 1995. Bolm Ag. Tec. Bacia do Paraíba do Sul. CPRM. 5p.

Edmondson, W. T. (ed). 1959. Fresh-Water Biology. 2. ed. John Wiley \& Sons. 1248p.

Elmoor-Loureiro, L. M. A. 1997. Manual de identificação de Cladóceros límnicos do Brasil. Brasília, DF: Ed. Universitária. 156p.

Elmoor-Loureiro, L. M. A.; Mendonça-Galvão, L. \& Padovesi-Fonseca, C. 2004. New Cladoceran records from lake Paranoá, central Brazil. Braz. J. Biol., 64 (3A):415-422.

Garrels, M. \& Mackenzie, F. T. 1971. Evolution of sedimentary rocks. New York:, Norton \& Co., 387p.

Hann, B. J. \& Zrum, L. 1997. Littoral microcrustaceans (Cladocera, Copepoda) in a praierie coastal wetland: Seasonal abundance and community structure. Hydrobiologia, 357:37-52.

Hobaek, A.; Manca, M. \& Andersen, T. 2002. Factors influencing species richness in lacustrine zooplankton. Acta Oecol., 23:155-163.

Kennish, M. J. 1990. Ecology of Estuaries: Anthropogenic Effects. v. 1. Boca Ratton, Fl.: CRC Press, 494p.

Kramer, K. J. M.; Brockmann, U. H. \& Warwick, R. M. 1994. Tidal Estuaries. Manual of Sampling and Analytical Procedures. Brussels-Luxemburgo, 304p.

Lansac Tôha, F. A. \& Lima, A. F. 1993. Ecologia do zooplâncton do Estuário do Rio Una do Prelado (São Paulo, Brasil). Acta Limnologica Brasiliensia. 6:82-96.

Lopes, R. M. 1994. Zooplankton Distribution in the Guaraú River Estuary (South-eastern Brazil). Estuar. Coast. Shelf Sci., 39: 287-302.

Lopes, R. M. 1996. Hydrography and zooplankton community structure: A comparative study among estuaries of the Juréia-Itatins Ecological Station (Southeastern Brazil). Nerítica, 10: 27-40.
Marazzo, A. \& Valentin, J. L. 2000. Daily variation of marine cladoceran densities in a tropical bay. Hydrobiologia, 428: 205-208.

Marazzo, A. \& Valentin, J. L. 2001. Spatial and temporal variations of Penilia avirostris and Evadne tergestina (Crustacea, Branchiopoda) in a tropical bay, Brazil. Hydrobiologia, 445:133-139.

Marazzo, A. \& Valentin, J. L. 2004. Population Dynamics of Pseudoevadne tergestina (Branchiopoda: Onychopoda) in Guanabara Bay, Brazil. Braz. Archs. Biol. Technol. 47 (5):713-723.

Miller, C. B. The zooplankton of estuaries. In: Ketchum, B. H. 1983. Estuaries and enclosed seas. Amsterdam: Elsevier, p. 103-149.

Miranda, L. B. de; Castro, B. M. de \& Kjerfve, B. 2002. Princípios de Oceanografia Física de Estuários. São Paulo: Edusp. 414p.

Montú, M. 1980. Zooplâncton do estuário da Lagoa dos Patos. I. Estrutura e variações temporais e espaciais da comunidade. Atlântica, (4):53-72.

Montú, M. \& Gloeden, I. 1986. Atlas dos Cladocera e Copepoda (Crustacea) do estuário da Lagoa dos Patos (Rio Grande, Brasil). Nerítica, 1(2):1-134.

Neves, I. F.; Rocha, O.; Roche, K. F. \& Pinto, A. A. 2003. Zooplankton community structure of two marginal lakes of the River Cuiabá (Mato Grosso, Brazil) with analysis of Rotifera and Cladocera diversity. Braz. J. Biol., 63 (2):329-343.

Nixon, S.W. 1981. Remineralization and nutrient cycling in coastal marine ecosystems. In: Neilson, B. J. \& Cronin, L. E. Estuaries and nutrients. New York: Humana Press. p. 111-138.

Nogueira, C. R.; Santos, L. H. S.; Bonecker, A. C. T.; Bonecker, S. L. C.; Dias, C. de O. \& Reis, J. M. L. 1999. Studies on zooplankton and ichthyoplankton communities off the Rio de Janeiro Coastline. In: Silva, S. H. G. \& Lavrado, H. P. eds. Ecologia dos ambientes costeiros do Estado do Rio de Janeiro, ser. Oecologia Brasiliensis. Rio de Janeiro: PPGE-UFRJ. v. 7. p.1-33.

Omori, M. \& Ikeda, T. 1992. Methods in Marine Zooplankton Ecology. Malabar, Fl.: Krieger Publish. Co. $329 \mathrm{p}$.

Resgalla Jr. C. \& Montú, M. 1993. Cladóceros marinhos da plataforma continental do Rio Grande do Sul - Brasil. Nauplius, 1:63-79.

Sampaio, E. V.; Rocha, O.; Matsumura-Tundisi, T. \& Tundisi, J. G. 2002. Composition and abundance of zooplankton in the limnetic zone of seven reservoirs of the Paranapanema River, Brazil. Braz. J. Biol., 62(3):525-545.

Santos-Wisniewski, M. J.; Rocha, O.; Guntzel, A. M. \& Matsumura-Tundisi, T. 2002. Cladocera Chydoridae of high Altitude water bodies (Serra da Mantiqueira), in Brazil. Braz. J. Biol., 62 (4A): 681-687.

Serafim Jr. M.; Lansac-Tôha, F. A.; Paggi, J. C.; Velho, L. F. M. \& Robertson, B. 2003. Cladocera fauna composition in a river-lagoon system of the upper Paraná River floodplain, with a new record for Brazil. Braz. J. Biol., 63(2):349-356.

Summerhayes, C. P. \& Thorpe, S. A. 1998. Oceanography. An Illustrated Guide. London:Manson Publishing., 352p.

Tundisi, J. G. 1970. O Plâncton Estuarino. Contrções Inst. oceanogr. Univ. S. Paulo, ser. Ocean. Biol., (19):1-22. 
Underwood, A. J. 1997. Experiments in ecology. Their logical design and interpretation using analysis of variance. Cambridge: Cambridge University Press. 504p.

Valentin, J. L. \& Marazzo, A. 2003. Modeling the population dynamics of Penilia avirostris (Branchiopoda Ctenopoda) in a tropical bay. Acta Oecol. 24:369-376.

Villate, F. 1997. Tidal influence on zonation and occurrence of resident and temporary zooplankton in a shallow system (Estuary of Mundaka, Bay of Biscay). Scientia Marina, 61(2):173-188.

Wooldridge, T. H. \& Callahan, R. 2000. The effects of single freshwater release into the Kromme Estuary. 3: Estuarine zooplankton response. Water SA., 26:311-318.
Sources of Unpublished Material

Carneiro, M. E. R. 1998. Transporte da matéria orgânica no Estuário do Rio Paraíba do Sul. Niterói: Universidade Federal Fluminense. PhD. Thesis. 200p.

(Manuscript received 30 January 2006; revised 07 August 2006; accepted 30 August 2006) 